\title{
Kombinasi Naive Bayes dan Metode Time Series Sebagai Peramalan Pergerakan Harga pada Perdagangan Valuta Asing
}

\author{
Muhamat Maariful Huda ${ }^{1, *}$, Rizki Darma Rusdiyan Yusron ${ }^{2}$ \\ Program Studi Ilmu Komputer, Universitas Nahdlatul Ulama Blitar, Indonesia \\ ${ }^{1}$ hudha.maariful@unublitar.ac.id; ${ }^{2}$ rizkyyusron@unublitar.ac.id \\ * corresponding author
}

INFO ARTIKEL

Sejarah Artikel

Diterima: 5 Juli 2020

Direvisi: 10 Agustus 2020

Diterbitkan: 30 Agustus 2020

Kata Kunci

Forecast

Naïve Bayes

Perdagangan Valas

Moving average

\section{ABSTRAK}

Dalam perdagangan valuta asing, terdapat data yang dapat diakses secara bebas dan berkelanjutan. Data yang tersedia antara lain: harga pembukaan, harga tertinggi, harga terendah dan harga penutupan, data tersebut adalah variable penting dalam memprediksi pergerakan harga kedepan. Data yang tersedia bukan hanya dari data perdagangan valuta asing, akan tetapi juga terdapat data perilisan berita dan analisa dari ahli perdagangan valuta asing. Dari beberapa sumber, data yang didapat berupa teks dan angka. Pendekatan yang dilakukan dalam penelitian ini adalah peramalan dengan mengkombinasikan data teks dan data numerik. Kombinasi yang digunakan dalam peramalan adalah metode text mining dengan beberapa metode dalam time series, antara lain : simple moving average, weighted moving average dan exponential moving average. Rentang waktu peneliatian mulai 1 Desember 2018 sampai dengan 31 Januari 2019 dengan 3 pasang mata uang, EUR-USD, USD-JPY dan EUR-JPY. Hasil dari peramalan menggunakan metode time series akan dibandingkan dengan kombinasi dari metode time series dan klasifikasi naïve bayes. Hasil dari percobaan menunjukkan bahwa kombinasi dari metode time series dan klasifikasi naïve bayes memiliki akurasi peramalan yang lebih baik

\section{PENDAHULUAN}

Perdagangan valuta asing atau forex trading, menjadi salah satu pasar finansial terbesar dengan perputaran uang mencapai 6 trilliun US dollar, dan $45 \%$ volume transaksinya dilakukan oleh pedagang retail[1]. Maka dari itu, metode peramalan dalam mentukan pergerakan harga adalah metode yang sangat dicari oleh para pelaku trading. Salah satu metode dalam peramalan yang sangat sering digunakan adalah metode time series, terdapat banyak variasi dalam metode time series, akan tetapi tujuannya tetaplah sama[2], yaitu untuk menentukan pergerakan harga selanjutnya. Metode paling sederhana dalam analisa time series adalah simple moving average atau yang lebih dikenal sebagai moving average, dimana dalam perhitungannya, setiap data dianggap memiliki bobot yang sama. Satu tingkat diatas moving average adalah weighted moving average, dalam metode ini, masing masing data yang akan dihitung diberikan factor pemberat dalam setiap data yang akan dihitung. Versi lain dari metode time series adalah exponential moving average, dalam metode ini digunakan fungsi exponensial sebagai basis dalam pembentukan factor pembobotannya. Ketiga metode tersebut sering digunakan dalam peramalan menggunakan metode time series[3][4][5].

Dalam penelitian ini, perhitungan dengan metode time series (moving average, exponential moving average, smoothed moving average), akan dibandingkan dengan kombinasi dari metode time series dan klasifikasi naïve bayes. Pasangan mata uang yang digunakan sebagai penelitian adalah EUR-USD, USD-JPY dan EUR-JPY. Selanjutnya akan 
dilakukan perhitungan kesalahan menggunakan metode mean square error (MSE), mean absolute percentage error (MAPE) dan mean absolute scaled error (MASE).

\section{METODE}

\section{Moving average}

Dalam metode time series, moving average adalah metode paling sederhana dan paling banyak digunakan. Setiap data dalam perhitungan metode ini memiliki bobot yang sama[6], rumus dari moving average dapat ditulis sebagai sebagaimana Persamaan (1):

$$
\bar{p}_{S M}=\frac{P m+P m-1+\cdots+P m-(n-1)}{n}
$$

Dimana Pm adalah data saat ini, Pm-1 adalah data sebelumnya, $\mathrm{n}$ adalah banyaknya data.

\section{Weighted moving average}

Setiap data yang akan digunakan dalam metode weighted moving average diberikan bobot, dimana pembobotan dari data sebelumnya lebih kecil dari data actual. Pemberian bobot dihitung dari jumlah data yang digunakan dalam perhitungan time series, cara pembobotan seperti ini dikenal juga dengan istilah 'sum of digit'[7]. Persamaan weighted moving average ditulis sebagai Persamaan (2) berikut:

$$
W M A m=\frac{n p M+(n-1) p M-1+\cdots+2 p(M-n+2)+p(M-n+1)}{n+(n-1)+\cdots+2+1}
$$

Dari Persamaan (2) diatas, $\mathrm{n}$ merujuk pada periode data yang digunakan, $\mathrm{pM}$ adalah nilai data pada periode $\mathrm{m}$.

\section{Exponential moving average}

Exponential moving average memberikan bobot yang lebih ringan kepada data sebelumnya[8]. Pada time series Y, persamaan exponential moving average secara rekursif[9] dapat ditulis sebagai Persamaan (3):

$$
S t=\left\{\begin{array}{cr}
Y_{1}, & t=1 \\
\alpha . Y t+(1-\alpha) . S t-1, & t>1
\end{array}\right.
$$

Dimana Yt adalah nilai data pada saat $\mathrm{t}$, St adalah nilai exponential moving average pada saat $\mathrm{t}$ dan $\alpha$ merepresentasikan konstanta dari factor penghalus dengan nilai antara 0 dan 1[10]. Nilai $\alpha$ dapat diestimasikan sesuai Persamaan (4):

$$
\alpha=\frac{2}{n+1}
$$

\section{Naïve bayes classifier}

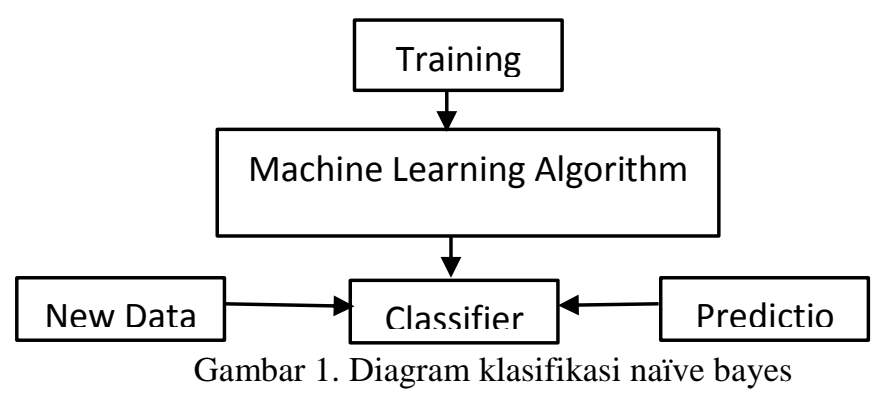

dalam penelitian ini, metode naïve bayes digunakan untuk mendapatkan nilai dari sentiment dari data teks yang dikumpulkan. Berdasarkan Gambar 1, data training yang dikumpulkan diolah dengan algoritma machine learning, selanjutnya hasil dari pengolahan machine learning diproses dalam classifier dengan data baru, hasil dari proses classifier adalah prediksi dari data teks. Penggunaan naïve bayes sebagai tools klasifikasi dikarenakan kemudahannya, proses komputasinya yang efisien, memiliki tingkat akurasi yang baik, dan 
juga dikarenakan banyak digunakan dalam pemrosesan data teks yang tidak sedikit[11]. Persamaan dari naïve bayes adalah sebagai Persamaan (5) :

$$
P(c \mid x)=\frac{P(x \mid c) P(c)}{P(x)}
$$

Dimana $\mathrm{x}$ adalah kata, $\mathrm{c}$ adalah katgori, $\mathrm{P}(\mathrm{x} \mid \mathrm{c})$ adalah probabilitas kata dalam kategori $\mathrm{c}$, $\mathrm{P}(\mathrm{x})$ adalah probabilitas dari kata, dan $\mathrm{P}(\mathrm{c})$ adalah probabilitas kategori. Atau dalam persamaan yang lain dapat ditulis sesuai Persamaan (6) :

$$
P(c \mid X)=P\left(x_{1} \mid c\right) \times P\left(x_{2} \mid c\right) \times P\left(x_{n} \mid c\right) \times P(c)
$$

\section{Kombinasi time series dan naïve bayes}

Setelah didapatkan sentiment dari proses klasifikasi naïve bayes dan proses dari metode time series, langkah selanjutnya adalah mengkombinasikan kedua sentiment baik dari data teks maupun data angka. Sumber dari data teks yang didapat adalah dari www.investing.com/analysis/forex dimulai dari tanggal 1 desember 2018 hingga 1 januari 2019, dengan batasan data yang dikumpulkan adalah artikel analisa teknikal, analisa fundamental, dan signal dari ahli ahli trading. Untuk data bertipe nomor, didapat dari tanggal 1 desember 2018 hingga 31 januari 2019 dari software yang banyak digunakan oleh pelaku trading, yaitu metatrader 4. Sebelum dikombinasikan, kedua data disaring dengan tanggal dan jam kemunculan yang sama. Didapat 54 data baik teks maupun nomor dengan kemunculan yang sama pada pasangan mata uang EUR-JPY, 195 data EUR-USD, 77 data USD-JPY, dimana masing masing data berisi harga pembukaan, harga tertinggi, harga terendah, dan harga penutupan.

\section{HASIL DAN PEMBAHASAN}

Setelah mendapat sentiment dari proses naïve bayes classifier dan juga didapatkan sentiment dari proses penghitungan metode time series, maka langkah selanjutnya data text dan dana angka yang memiliki tanggal dan jam yang sama kemunculannya. Penggabungan antara teks dan angka dapat dirumuskan sebagai Persamaan (7) :

$$
C=N_{t}-N_{t-1} \quad(7)
$$

Dimana dalam persamaan diatas, $\mathrm{C}$ adalah derajat untuk dari sebuah nilai itu naik atau turun, $\mathrm{Nt}$ adalah harga mata uang pada saat ini, dan Nt-1 adalah adalah harga mata uang pada saat sebelumnya. Sedangkan untuk persamaan kombinasi antara teks dan angka dirumuskan sebagai Persamaan (8):

$$
\text { Prediction }=N_{t}+(C \times \text { Decission } \times \text { Degree })
$$

Tabel 1. Kombinasi teks dan angka

\begin{tabular}{|c|c|c|c|c|}
\hline Text & angka & Text + angka & Decission & degree \\
\hline 1 & 1 & 2 & Positive & Full $(1)$ \\
1 & 0 & 1 & Positive & Half $(0,5)$ \\
1 & -1 & 0 & Stagnan & $0(0)$ \\
0 & 1 & 1 & Positive & Half $(0,5)$ \\
0 & 0 & 0 & Stagnan & $0(0)$ \\
0 & -1 & -1 & Negative & Half $(0,5)$ \\
-1 & 1 & 0 & Stagnan & $0(0)$ \\
-1 & 0 & -1 & Negative & Half $(0,5)$ \\
-1 & -1 & -2 & negative & Full $(1)$ \\
\hline
\end{tabular}

Pada tabel diatas, ketika teks bernilai positive (1) dan angka bernilai positive(1), maka didapat angka 2 hasil dari penjumlahan dati teks dan angka, yang artinya dalam penerapan peramalan pergerakan harga akan naik secara penuh (positive full). Ketika teks bernilai 
positive (1) dan angka bernilai stagnan (0) maka didapat angka 1 yang artinya adalah pergerakan harga mata uang diramalkan akan naik akan tetapi hanya sebagian ( positive half). Berikut contoh penerapan peramalan:

Tabel 2. Contoh peramalan dengan decission degree

\begin{tabular}{|c|c|c|c|c|c|c|}
\hline No & Nt & Nt-1 & C & Decision & Degree & Prediction \\
\hline 1 & 1.13545 & 1.13515 & 0.00031 & Positive & 1 & 1.13564 \\
2 & 1.13471 & 1.13470 & 0.00001 & Positive & 0.5 & 1.13521 \\
3 & 1.13680 & 1.13680 & 0.00000 & Stagnan & 0 & 1.13680 \\
4 & 1.13798 & 1.13745 & - & Negative & 0.5 & 1.13748 \\
5 & 1.13820 & 1.13937 & 0.00053 & Negative & 1 & 1.13920 \\
& & & - & & & \\
& & & 0.00117 & & & \\
\hline
\end{tabular}

Pada nomor 1, mata uang EUR-USD pada tanggal 5 desember 2019, harga pembukaan adalah 1.13545, dimana harga sebelumnya adalah 1.13515 , dengn nilai $\mathrm{C}=0.0031$ dan nilai prediksi teks didapat positive maka permalan nilai selanjutnya adalah harga akan naik pada angka 1.13645, dengan asumsi jika positive full maka angka akan naik 100 poin, pada contoh nomor 2, dengan pendekatan yang sama dengan contoh sebelumnya, didapat nilai positive half, dimana nilai akan diramalkan naik 50 poin, pada kisaran 1.1352 .

Dengan menggunakan data angka sebanyak 1.304, didapat dari history center di metatrader 4, dengan filter kemunculan tanggal yang sama dengan data teks, ditambah data teks yang didapat dari www.investing.com/analysis/forex dengan filter untuk data teknikal, data fundamental dan data sinyal. Setelah digabungkan data teks dengan data angka, kemudian dibandingkan dengan penghitungan data angka menggunakan metode time series, dilakukan pengujian error dengan tiga metode, diantaranya: MAPE ( Mean Absolute Percentage Error), MSE (Mean Scale Error), MADE (Mean Absolute Deviation Error). Didapat hasil sebagaimana Tabel 4:

Tabel 4. Perhitungan error EUR-JPY

\begin{tabular}{|c|c|c|}
\hline \multicolumn{3}{|c|}{ Hitung Error EUR-JPY (open) } \\
\hline & $\begin{array}{c}\text { Moving } \\
\text { average }\end{array}$ & $\begin{array}{c}\text { Moving average } \\
\text { + Naïve Bayes }\end{array}$ \\
\hline MADE & 0.179196226 & 0.055660377 \\
MSE & 0.082453225 & 0.004952830 \\
MAPE & 0.001431293 & 0.000433787 \\
\hline
\end{tabular}

Tabel 5. Perhitungan error EUR-JPY

\begin{tabular}{|l|l|l|}
\hline \multicolumn{3}{|c|}{ Hitung Error EUR-JPY (open) } \\
\hline & $\begin{array}{l}\text { Weighted } \\
\text { Moving } \\
\text { average }\end{array}$ & $\begin{array}{l}\text { Weighted } \\
\text { Moving average } \\
\text { + Naïve Bayes }\end{array}$ \\
\hline MADE & 0.137152564 & 0.057692308 \\
MSE & 0.040575256 & 0.005192308 \\
MAPE & 0.001094151 & 0.000458048 \\
\hline
\end{tabular}


Tabel 6. Perhitungan error EUR-JPY

\begin{tabular}{|l|l|l|}
\hline \multicolumn{3}{|c|}{ Hitung Error EUR-JPY (open) } \\
\hline & $\begin{array}{l}\text { Exponential } \\
\text { Moving } \\
\text { average }\end{array}$ & $\begin{array}{l}\text { Exponential } \\
\text { Moving average } \\
+ \text { Naïve Bayes }\end{array}$ \\
\hline MADE & 0.149960377 & 0.056603774 \\
MSE & 0.036000022 & 0.005094340 \\
MAPE & 0.001193931 & 0.000449892 \\
\hline
\end{tabular}

\section{KESIMPULAN}

Pada perhitungan error menggunakan tiga metode, MADE (Mean Absolte Deviation Error), MSE (Mean Squre Error) dan MAPE (Mea Absolute Percentage Error) didapat nilai kesalahan yang lebih kecil, ini membuktikan bahwa dengan menggabungkan metode pramalan time series ( MA, EMA dan WMA) dan peramalan teks (naïve bayes classifier), didapat hasil peramalan yang lebih baik

\section{REFERENSI}

[1] L. Ni, Y. Li, X. Wang, J. Zhang, J. Yu, and C. Qi, "Forecasting of Forex Time series Data Based on Deep Learning," Procedia Comput. Sci., vol. 147, pp. 647-652, 2019.

[2] Y. Zhu and G. Zhou, "Technical analysis: An asset allocation perspective on the use of moving averages," J. financ. econ., vol. 92, no. 3, pp. 519-544, 2009.

[3] D. Kapgate, "Weighted Moving average Forecast Model based Prediction Service Broker Algorithm for Cloud Computing," Int. J. Comput. Sci. Mob. Comput., vol. 3, no. 2, pp. 71-79, 2014.

[4] A. Raudys, V. Lenčiauskas, and E. Malčius, "Moving averages for financial data smoothing," Commun. Comput. Inf. Sci., vol. 403, pp. 34-45, 2013.

[5] X. F. Hui and Y. J. Wu, "Research on simple moving average trading system based on SVM," Int. Conf. Manag. Sci. Eng. - Annu. Conf. Proc., no. 71031003, pp. 1393-1397, 2012.

[6] C. A. Ellis and S. A. Parbery, "Is smarter better? A comparison of adaptive, and simple moving average trading strategies," Res. Int. Bus. Financ., vol. 19, no. 3, pp. 399-411, 2005.

[7] S. Hansun, "A new approach of moving average method in time series analysis," pp. 1-4, 2014.

[8] J. S. Hunter, "The Exponentially Weighted Moving average," J. Qual. Technol., vol. 18, no. 4, pp. 203-210, 2018

[9] S. Hansun, "FX forecasting using B-WEMA: Variant of Brown's Double Exponential Smoothing," 2016 Int. Conf. Informatics Comput. ICIC 2016, no. Icic, pp. 262-266, 2017.

[10] F. R. Johnston, J. E. Boyland, M. Meadows, and E. Shale, "Some properties of a simple moving average when applied to forecasting a time series," J. Oper. Res. Soc., vol. 50, no. 12, pp. 1267-1271, 1999.

[11] I. Yanuar Risca Pratiwi, R. Andrie, and F. Rahutomo, "Study of hoax news detection using naïve bayes classifier in Indonesian language," 2017, pp. 73-78. 